\title{
Protecting the Consumer Rights in the Digital Economic Era: Future Challenges in Indonesia
}

\author{
Ridwan Arifin ${ }^{1}$, Juan Anthonio Kambuno ${ }^{2}$, Waspiah ${ }^{3}$, Dian Latifiani ${ }^{4}$ \\ ${ }^{1}$ Faculty of Law, Universitas Negeri Semarang, Indonesia. E-mail: ridwan.arifin@mail.unnes.ac.id \\ ${ }^{2}$ Faculty of Law, Universitas Negeri Semarang, Indonesia. E-mail: kambunojuan@gmail.com \\ 3 Faculty of Law, Universitas Negeri Semarang, Indonesia. E-mail: waspiah@mail.unnes.ac.id \\ ${ }^{4}$ Faculty of Law, Universitas Negeri Semarang, Indonesia. E-mail: $\underline{\text { dianlatifiani@mail.unnes.ac.id }}$
}

\section{Article Info}

\section{Keywords:}

Consumer Protection;

Digital Economic Era;

Data Privacy; Indonesian

Policy

\section{How to cite (APA Citation} Style):

Arifin, R, et al. (2021). “

Protecting the Costumer

Rights in the Digital

Economic Era: Future

Chalangges in Indonesia".

Jambura Law Review.

JALREV 3 Special Issue:

$135-160$

\begin{abstract}
The emerging technological prospects affected many aspects, including consumer protection. The creation of data and computer-driven innovation would derive several advantages for consumers. Innovative products and services and new ways in which goods and services are developed and delivered. This paper aims to analyse how Indonesian legal policy on protection consumer rights in the digital era. The paper emphasized that it would advise against believing that policy is unreasonably permitted to give way to the technological agenda, whilst accepting that adaptations should be made and also that there should be a critical review of whether existing forms of regulation are needed in the digital economy of Indonesia. Regulations concerning to the protecting consumer rights in the world of e-commerce are still worrying even though many sectoral regulations have been promulgated, as well as weak supervision and lack of strict law enforcement in resolving consumer disputes. Trade regulation via the internet still raises many conceptual or theoretical questions that indicate the need to develop more detailed conceptual and theoretical explanations to the need for more complex laws and regulations to be able to protect consumers properly. More than that, national regulations are dealing with the context of trade through the internet, which transcends national boundaries without always being controlled through conventional means.
\end{abstract}




\section{Introduction}

Technological advancements promote a country's development by creating incentives for any new innovations and by fostering industry, commerce, finance, investment, and even institutional capability growth. Technology has similarly facilitated poverty alleviation in Indonesia by increased communication, consumption, development, and job growth. This has shifted the economy into a digital transformation with the advance growth of Indonesian economy which certainly provokes a new and increasingly interesting debate.

The digital economy continues to develop in the country, and even Indonesia is considered to have great potential because the penetration rate of internet users continues to increase. This has provided an open platform that reduces transaction costs for starting a business, regardless of who is trying to start one. The advantages for entrepreneurs from this are providing wider, faster, more affordable, and reliable choices to its customers 5 . The value of Indonesia's digital economic transaction is the largest in Southeast Asia. Indonesia itself is a potential market for the digital economy. The magnitude of digital economic potential in Indonesia is evidenced by the value of US\$ 20 million in 2016. And in 2025, the value is projected to reach US\$ 133 billion or about Rp. 1.826 trillion, with contributions in various sectors such as e-commerce US\$ 21 million (2019), e-travel US\$ 10 million (2019) and transportation US\$ 25 million (2019). The rapid development of the digital economy in Indonesia is due to the significant flow of foreign investment, rapid development of the consumer class, high penetration of smartphones, and the evolution of payment infrastructure that facilitates online purchases. ${ }^{6}$

However, with the progressive development of Indonesian economy in the 21st century has too created a big problem which one of them is consumer protection in

5 Dewa Gede Sidan Raeskyesa, and Erica Novianti Lukas. (2019). 'Does Digitalization Increase Economic Growth? Evidence from ASEAN8 Countries'. Jurnal Ekonomi Indonesia 8 (2). Retrieved from http://jurnal.isei.or.id/index.php/isei/article/view/33.

$6 \quad$ Fetry Wuryasti. (2020). "Potensi Besar Ekonomi Digital Indonesia". Media Indonesia. Retreved from https://mediaindonesia.com/ekonomi/354089/potensi-besar-ekonomi-digital-indonesia. 
accessing digital transactions. The growth of product development and digital facilities has pushed the government, industries, and consumers to be adapted with a new business model as the digital transaction proceeds without inspection, examination or product evaluation, therefore digital literacy is needed in order for consumers to understand the terms and conditions of payment system and electronic transactions required. A survey from GBG stated 55\% of identity forgery and 53\% of stolen identity happened from money mules which risk 175.4 million internet users in Indonesia from potential violations ${ }^{7}$. 3.130 reports of cybercrime cases received throughout January to July in 2019 by the National Police's Criminal Investigation Directorate ${ }^{8}$. Reports on online fraud are the most dominant, which is 1.243 cases. The Indonesian Consumers Foundation (YLKI) recorded online shopping complaints ranked third, accounting for $6.3 \%$ of 563 individual category complaints ${ }^{9}$. A common complaint is hacking of consumer e-commerce accounts. Criminals usually hack or cheat on behalf of the marketplace ${ }^{10}$. In principle, consumers should have the option to file a complaint with the relevant business actors, and if necessary, process it through various means, such as reporting it to the authorities, out-of-court settlement (e.g., alternative dispute resolution), and litigation. However, consumers in Indonesia are not quite active in reporting complaints. Even though this is already guaranteed by the existing laws in

7 GBG, and The Asian Banker. (2020). 'Future-Proofing Fraud Prevention in Digital Channels: Indonesia's Financial Institution Study'.

$8 \quad$ Lidwina, Andrea. (ed. October 31. 2019). 'Penipuan Online, Kejahatan Siber Yang Paling Banyak Dilaporkan'. Databoks. Retrieved from https://databoks.katadata.co.id/datapublish/2019/10/31/penipuan-online-kejahatan-siberpaling-banyak-dilaporkan.

9 M. Agus Yozami. 'Meneropong Perlindungan Konsumen Jasa Finansial Di Tahun Tikus Logam'. Hukumonline.com. $\quad$ Accessed $\quad 1 \quad$ September 2020. https://www.hukumonline.com/berita/baca/lt5e54e4e9c5d97/meneropong-perlindungankonsumen-jasa-finansial-di-tahun-tikus-logam?page=all/.

10 Merlyna Lim. (2013). "The Internet and Everyday Life in Indonesia: A New Moral Panic?”. Journal of the Humanities and Social Sciences of Southeast Asia 169 (1). https://doi.org/10.1163/2213437912340008. 
Indonesia; As well as most disputes often experience many obstacles and rarely give satisfactory results. The lack of consumer complaints can also be caused by the lack of knowledge of consumers regarding their rights and the institutions responsible for consumer protection. The difficulties that arise in disputes between parties in digital transactions are related to the choice of law that will be applied as the basis for resolving the dispute. The problem of choice of law and court can occur because digital transactions are not only carried out by domestic parties, but also by parties from different countries.

\section{Problem Statement}

It is a brief statement about the standing position of the problem to be studied.

Therefore, before doing the who.e set of the fifth amendment of the Constitution of NRI 1945 , it is necessary to examine the formation of a constitutional commission in the amendment to the Constitution of NRI 1945 to the fifth amendment, with the boundary problem will be described are, first, Any corrections to the Constitution of NRI 1945 which need to be improved and perfected on the fifth amendment. Second, Do Constitutional Commission before the fifth amendment made will reduce the authority of the Assembly in conducting NRI Constitution Amendment of 1945.

\section{Method/ Approach}

The data used this paper is based on the nature of the juridical-normative approach with the application of statute approach. ${ }^{11}$ The data analysed is conducted in the method of qualitative technique which is synchronising and interpreting the provisions of the related consumer law in a legal manner. As for the legal material, it will be used as primary legal material which consists of binding legal materials, such as basic norms or rules, basic regulations, laws and regulations, jurisprudence, and so on. This refers to the legal books in Indonesia such as the Civil Code and the Consumer Protection Act. Meanwhile, secondary legal materials, which provide an explanation of

11 Theresia Anita Christiani. (2016). "Normative and Empirical Research Methods: Their Usefulness and Relevance in the Study of Law as an Object". Procedia - Social and Behavioral Sciences 201207: 1-856. https://doi.org/10.1016/j.sbspro.2016.05.006. 
primary legal materials, including the Principles of Civil Law, and other legal materials that can be obtained from the results of research include books, journals, notes, documents, articles, internet, reports, and also others relating to the discussion of consumer protection. In collecting legal materials related to this research, it is pursued through library research by reviewing books or scientific works related to research problems, reviewing the literature taken or obtained from primary and secondary material sources. ${ }^{12}$

\section{Analysis and Discussion}

\section{A. Consumer Rights Protection: How Indonesian Policies Said?}

Consumer protection law is the basic concept and laws regulating and preserving consumers in the sense of the interaction and complexities of the production and usage of consumer goods between manufacturers and their common usage. Regulations on consumer protection are not only based on acts that specifically regulate consumer protection, namely Act No. 8 of 1999 concerning Consumer Protection. However, it also includes general legislation, which also regulates consumer protection issues, namely as follows:

\section{1) Act No. 8 of 1999 concerning Consumer Protection}

When talking about consumer protection law then we should also talk about Consumer Protection Act No. 8 of 1999. The Consumer Protection Act was born as the solution to today's economy's growth and development. When opposed to business actors, customers are always in a weakened or unbalanced role as the driving force in the economy and can become a weapon in business practices to reap the greatest income from business actors.

The Consumer Protection Act concerning consumer protection has been in effect since April 20, 1999. In order to satisfy their interests as customers, this act controls in detail the provision of protection to customers. The relevant legal scope of the

12 Laurensius S. Arliman. (2018). 'Peranan Metodologi Penelitian Hukum Di Dalam Perkembangna Ilmu Hukum Di Indonesia'. Soumatera Law Review 1 (1). https://doi.org/10.22216/soumlaw.v1i1.3346. 
rights and obligations of customers, business actors, and the mechanism by which those rights and obligations are preserved. Act No. 8 of 1999 concerning consumer protection, ideally a smooth sale and purchase transaction will bring satisfaction and convenience for sellers and buyers. Any products and services offered by the seller should satisfy or meet the standards and expectations of the buyers. This also includes the business of buying and selling property, which needs to be done with extra caution as it is very vulnerable to problems.

Although it has been around for a long time in the last two decades, this consumeroriented legal umbrella has not been much realized by consumers themselves. Many consumers think this act is really needed when they are involved in criminal or civil cases only. In fact, if consumers (including us) want to be more literate, we become more aware of the intricacies of consumer problems treated unfairly and how to fight for their rights.

There are other consumer obligations relating to consumer empowerment and the right to knowledge, as required by the Consumer Protection Act. These obligations mean that consumers are required to read the details, guidelines, implementation or use procedures referred to in Art. 5a, which means that consumers have a duty to make responsible choices available to them. While business actors are supposed to act responsibly towards their consumers. The external protection element is referred to by regulation, but liability for damage to consumers is referred to only in the latter provisions of the Consumer Protection Act, and not as a primary purpose. In relation to consumer dispute, this concept broadly applies to the level of judgment, consideration, prudence and knowledge that can logically be required to be provided by a customer when purchasing goods and services. To put it another way, the courts may investigate whether the complainant has been sufficiently vigilant and that, in itself, the standard of proof on customers in the context of contractual and other disputes may face considerable challenges.

The Consumer Protection system set up in the Consumer Protection Act is no longer adequate, especially given the development of the times in the digital economy era. The Consumer Protection Act must be revised to be able to accommodate as much as 
possible consumer protection needs in the future. Thus, the integrity of consumer protection can build mutual trust between business actors and consumers effectively and fairly. The Consumer Protection Act legally regulates consumer rights and obligations as well as the responsibilities of business actors in conventional/traditional transactions, while consumer protection in transactions using electronic systems cannot fully refer to the Consumer Protection Act. Electronic transaction arrangements are then regulated in Act No. 11 of 2008 concerning Electronic Information and Transactions as amended by Act No. 19 of 2016 on Amendments to Act No. 11 of 2008 on Information and Electronic Transactions. Sectoral consumer protection arrangements tend to be nervous and stutter when having to deal with various consumer protection incidents in the digital age. The Consumer Protection Act has not included data protection and security for digital transactions such as cryptography techniques and policy on e-commerce provider privacy. Regulations related to what types of data can be collected by the provider and how they are allowed to process them are also still not consolidated due to differences and overlapping rules between Information and Electronic Transactions Act, Trade Act No. 7 of 2014 and Government Act No. 80 of $2019 .{ }^{13}$

The protection of digital consumers and the problems that arise from legal loopholes have made the Act need to be revised as this is an urgent priority. The Consumer Protection Act has been identified by the Indonesian government as a target to be revised. Unfortunately, according to the 2020-2024 National Legislation Program, the draft bill was ranked 123 of 248 draft bills to be reviewed and accepted by the DPR, which unfortunately went down 21th place compared to the previous National Legislation 2015-2019. It is very uncertain that, for the remainder of the present statutory cycle, an amendment or revision to the existing Consumer Protection Act would be necessary.

13 Indra Kirana Darajat. (2014). 'Perlindungan Hukum Bagi Pelaku Usaha Dan Konsumen Dalam Transaksi Jual Beli Secara Online Dengan Pembayaran Melalui Paypal'. E-Journal Graduate Unpar 1 (2). http://journal.unpar.ac.id/index.php/unpargraduate/article/view/1041/1159. 


\section{2) Acts and Regulation Concerning E-Commerce}

The everlasting question continues to emerge between law and technology. As one of the models of information technology, the superiority of the internet offers a complex response to the legal problems that arise. The response to the development of foreign trade is the use of the internet media as a new trade path. The growth of trade transactions using electronic means or, later, e-commerce was pioneered by the Internet. The rapid growth of e-commerce around the world has had its own impact on Indonesia. According to DBS, Indonesia is the biggest e-commerce market in Asia with the transaction values reaching US\$ 1.1 million in 2014 which exceeded Thailand and Singapore. ${ }^{14}$

Significantly, most of the law of e-commerce in Indonesia does not cover aspects of transactions carried out online (internet). However, there are several laws that can be used to conduct online transactions or e-commerce activities. Act No. 7 of 2014 on Trade (Trade Act) and Act No. 8 of 1999 on Consumer Protection (Consumer Protection Act) are a guide for any business actors the conduct of commercial transactions, whether traditional or on-line or e-commerce. The scope of regulation in Trade Act includes domestic and foreign trade, border trade, licensing, standardization, trade through electronic systems, trade protection and security, cooperative empowerment as well as micro, small and medium enterprises, export development, duties and authorities, international trade cooperation, trade information system, national trade committee, supervision and investigation. E-commerce requires that any individual or organization that trades products or services must have full and reliable data and information which is written in Chapter VIII Art. 65-66 concerning trading through electronic systems. Meanwhile further provisions are regulated in the Government Regulation such as GR No. 80 of 2019 concerning electronic commerce, GR No. 71 of 2019 concerning application of electronic systems and transactions, and so on.

14 Yura Syahrul. (2015). 'Indonesia, Pasar E-Commerce Terbesar Di ASEAN Dengan Banyak Kendala'. Katadata.co.id. Retrieved from https://katadata.co.id/yurasyahrul/indepth/5e9a56e366037/indonesia-pasar-e-commerceterbesar-di-asean-dengan-banyak-kendala. 
The Trade Act requires businesses to deliver comprehensive and transparent information in compliance with Act No. 19 of 2016 concerning electronic information and transactions (ITE Act). Electronic Information and Transaction Act is a provision that applies to every individual who commits a legal act as regulated in this Act, both within the jurisdiction of Indonesia and outside the jurisdiction of Indonesia, which has legal consequences in the jurisdiction of Indonesia and/or outside the jurisdiction of Indonesia and to the detriment of Indonesian interests; regulate various legal protections for activities that utilize the Internet as a medium, both transactions and the use of information; And arranged various threats of punishment for crimes through the internet. This Act accommodates the needs of business actors on the internet and the general public in order to obtain legal certainty, acknowledging electronic evidence and digital signatures as valid evidence in court.

Legal protection in electronic transactions should place an equal position between online business owners and consumers. Although seen as a virtual transaction, electronic transactions in e-commerce in Indonesia must remain subject to the provisions set out in the Consumer Protection Act. The existence of the Electronic Information and Transaction Act can be used as a legal partner of Consumer Protection Act to support each other. Returning to the Electronic Information and Transaction Act it is clear, that the key concept of electronic transactions is an arrangement or "as decided" between the parties (in this case business actors and consumers). Electronic transactions connect the parties to the agreement in such a way that, in terms of consumer security, customers who perform electronic transactions are deemed to have settled on all the terms and conditions that apply to the transaction. This refers to the typical clauses compiled by business actors that use internet media. While the Act stipulates the standard contract as set out in a document and/or an agreement is prohibited for entrepreneurs, this allows standard contract in e-commerce transactions to place an imbalance between business actors and customers. In Indonesia, the ITE Act states that electronic transactions can be entered into electronic contracts which can be determined of which legal option is used in resolving disputes. Parties in e-commerce disputes may decide which arbitration, court forum, or other alternatives are chosen in the e-contract. And if the court does not take place, the 
solution will return to the acts of international civil law. The application in the fields of commercial contracts has always been contentious. On one side, it should represent the difference between the negotiating power of consumers and professionals. On the other side, the contract must maintain a degree of equilibrium between parties. ${ }^{15}$

Other than the transitions of business actors to the digital world, today's digital technology is already influencing business in both traditional markets and other existing forms of modern business. This is because the market boundaries are very broad and unlimited (borderless), therefore it is necessary to have a common perception in business competition law to face the era of e-commerce around the world. As e-commerce is rapidly developing, it is possible to trade between countries which, because of predatory prices, could lead to unhealthy competition and foreign businesses selling goods to very cheap prices with the purpose of killing its competitors in e-commerce platforms. Consumers may get the benefit from healthy competition because it can lead to lower prices and product quality remains guaranteed. However, any competition that occurs is not healthy, will be able to damage the economy of the country which is detrimental to the community ${ }^{16}$.

\section{B. Consumer Protection in Indonesia: what are the challenges?}

\section{1) Personal Data Protection and Cyber Security}

Cyberspace reveals a growing pattern which is accompanied by numerous issues that may interfere with the law, not only in breach of the law, but potentially puts citizens, organisations and even the world at risk. To preserve protection in cyberspace, it must be secured. Cyber security is procedures and practices intended to deter malicious

15 I Gusti Ngurah Parikesit Widiatedja. (2017). 'Incorporating Local Wisdom Into the Consumer Protection Legal Regime: A Comparison Between Indonesia And Australia'. Udayana Journal of Law and Culture 1 (1). https://doi.org/10.24843/UJLC.2017.v01.i01.p03.

16 Melisa Setiawan Hotana. (2018). "Industri E-Commerce Dalam Menciptakan Pasar Yang Kompetitif Berdasarkan Hukum Persaingan Usaha". Jurnal Hukum Bisnis Bonum Commune 1 (1). https://doi.org/doi.org/10.30996/jhbbc.v0i0.1754. 
threats, losses or access to networks, devices, programs and records, and to protect information against some sort of deliberate activity, thereby endangering secrecy, integrity and access to data ${ }^{17}$. One of the Indonesian Act regulating cyber crime is in Act No. 19 of 2016 concerning Amendment No. 16 of 2008 on Electronic Information and Transactions.

In fact, in Indonesia there are not any regulations that protect the confidentiality of personal data. Regulations related to personal data already exist, but they are spread across 32 regulations. The regulations are still implicitly spread across various levels of legislation in Indonesia, separate and fragmented depending on each sector ${ }^{18}$. Until now, personal data protection as in general is only regulated in Ministerial Regulation No. 2 of 2016, which means that the absence of this law can facilitate misuse of consumer data for other purposes. This is because the community does not have a reference to protect their data given to other parties. For example, social engineeringbased fraud mode mostly uses the topic of lucky draws, advance-fee scams, hacking of corporate emails, website forgery, phishing; The topic of psychological manipulation began to develop by requesting access to OTP codes for victims' financial transactions, and requesting verification codes for telecommunications service providers via SMS or telephone. Moreover, the punishment for violating is only at administratif sanctions and criminal fines. Therefore, if there is misuse of user data and the site is decided to be blocked, then that only be temporary due to the site having the right to unblock if the sanction has stopped.

However, this draft bill also has not been regulated in relation to the establishment of commissions that serve as supervisors, regulators and monitors. The role of the commission with the nature of independence and impartiality is an important factor, considering that only they are actually in the midst of industry and government.

17 Mochammad Fahlevi, Mohamad Saparudin, Sari Maemunah, Dasih Irma, and Muhamad Ekhsan. (2019). “Cybercrime Business Digital in Indonesia'. E3S Web of Conferences 125, no. 21001. https://doi.org/doi.org/10.1051/e3sconf/201912521001.

18 Fanny Priscyllia. (2019). "Perlindungan Privasi Data Pribadi Perspektif Perbandingan Hukum'. Jatiswara 34 (3). https://doi.org/doi.org/10.29303/jatiswara.v34i3.218. 
Regulations on the protection of personal data as much as possible should provide clear core tasks and functions to the relevant agencies and organizations so that there is no overlap of authority. There is also concern that problems in the institutional structure will arise when there is overlapping authority between them. However, President Joko Widodo stated that there should not be another institution to be formed to execute personal data protection due to that it might disrupt the presidential system, extending the budget spending and widering the bureaucracy. Provisions regarding the transfer of personal data between countries must also meet internationally accepted standards. Indonesia should not disclose or provide the data they have to other countries for any purposes even in a way that is lawful before the law, if that country does not have regulations that are not at equivalent to the level of protection provided by the Indonesian Personal Data Protection Act bill. Moreover, all legal instruments from other countries including Indonesia should also adapt with international regulations such as EU General Data Protection Regulation, OECD Guidelines, ASEAN Framework on Personal Data Protection and APEC Privacy Framework ${ }^{19}$.

When this draft bill is implemented, it may take years to evolve in order for companies to adhere, raise awareness or implement law-complementary guidance in areas where holes can occur, particularly when new technological technologies are adopted at a rapid cycle. While acknowledging the interests of multiple constituencies, lawmakers should note that a measured of data privacy act is important to the protection of consumers, and stalling it will not be beneficial to the society. According to Wahyuni Djafar, Deputy Director of Research at the Institute for Community Studies and Advocacy (ELSAM), said that after the Personal Data Protection Bill is passed, there will usually be a transition period which takes approximately 2 to 3 years after the law is passed. Given the precedent of the Indonesian legal process, the propensity of the government to take a substantial period of time to formulate technical legislation in order to expand the transfer process is of concern. Furthermore, in several

19 Sinta Dewi Rosadi. (2018). 'Protecting Privacy On Personal Data In Digital Economic Era: Legal Framework In Indonesia'. Brawijaya Law Journal 5 (1). https://doi.org/dx.doi.org/10.21776/ub.blj.2018.005.01.09. 
organisations further reforms have to be made to the corporate sector to require time. This is because it is believed that data protection laws bind not just the online sector, but also the offline sector.

\section{2) The Cross-Border Digital Transactions}

In the era of globalization, the current business practice based on free trade is highly dependent on information technology. Trade using the means of the internet, of course, provides very high convenience and efficiency for consumers who need products that are simple in nature and belong to those that require delivery between countries.

Transactions that are borderless across the country, raise questions about which state's legal jurisdiction should apply. Clauses on legal options generally apply to cross-border e-commerce. The choice of law concerns the law of which country will be used in the event of a dispute, in this case a dispute between the consumer and the businessman located abroad.

There are two ways of resolving consumer disputes in Indonesia wich are out-of-court consumer disputes and through the general court. The process of resolving consumer disputes is done outside the court in Indonesia, namely through the Consumer Dispute Settlement Agency (BPSK) which are funded by local governments at the provincial level. Out-of-court consumer disputes are held to reach an agreement on the form and extent of the compensation, and/or on specific actions to ensure that the losses suffered by the consumer do not recur. The basis for the establishment of this institution is to deal with the resolution of disputes between consumers and business actors. The settlement process is pre-trial, then both parties agree to choose a dispute resolution through arbitration, mediation, or consolidation. This process is meant to resolve disputes between the parties, with or without authority/companion for each party, through peaceful means ${ }^{20}$.

20 Abdul Atsar, and Rani Apriani. (2019). "Buku Ajar Hukum Perlindungan Konsumen". Yogyakarta: CV. Budi Utama. p. 84-102. 
If the attempt is declared unsuccessful by either party or by the disputing parties, then this process can be continued to resolve the dispute through court (litigation). Consumer dispute resolution using litigation is a dispute resolution through a court that refers to the provisions of general court. The problem of the litigation process is the process of execution after the consumer as the plaintiff wins resulting in his rights as the consumer being discredited because the defendant (business actor) cannot return his property by issuing a verdict.

In the International realm, Indonesia is not yet a member of the International Consumer Protection and Enforcement Network (ICEPN) which is a network comprised of consumer protection law enforcement authorities worldwide. However, Indonesia is primarily part of the ASEAN Committee on Consumer Protection (ACCP), International Organization for Standardization/Committee on Consumer Policy (ISO/COPOLCO), Regional Comprehensive Economic Partnership (RCEP), which its efforts are to implement and monitor regional and international arrangements and mechanisms to foster consumer protection, as well as high levels of cooperation to further cover dispute settlement and e-commerce issues ${ }^{21}$.

In trade transactions on the internet where the traffic of business and consumer relations is getting closer and more open, state intervention, inter-state cooperation and international cooperation are very much needed, namely to regulate the pattern of business relationship between consumers and consumer protection systems. Legal protection of consumer rights in e-commerce transactions cannot be provided by one aspect of law alone, but by a system of legal devices capable of providing simultaneous and comprehensive protection.

\section{3) Consumer Rights: the challenges in educating people}

The e-commerce for consumers is rising increasingly and provides significant potential economic and consumer benefits. These advantages would however be

21 Guan Yue,, Dwidja Priyatno, and Anita Kamilah. (2019). 'A Comparison Between Chinese ECommerce Laws And Indonesian Information And Electronic Transactions Laws Against CrossBorder Online Services'. International Journal of Scientific \& Technology Research 8 (10): 89-94. 
compromised if customers were not sufficiently covered, which could result, along with an overall reduction in consumer interest in the market, in financial and other losses for individual consumers. If the economy was adequately controlled, a lack of customer trust could well lead to decreased growth opportunities and economic and consumer benefits otherwise present.

It would certainly be the case that the large number of violations of the legislation will be perpetrated by minor, local businesses who take advantage of uneducated, less savvy customers. It is this sort of scenario, in which the consumer is most in need of security, where protection would be the most difficult to come across. Although the educational purposes of the legislation are laudable, it would be difficult to reach the large rural regions where many of the more flagrant violations will occur, particularly if the closest consumer protection agency is situated many miles away and the prepetrator is a small and itinerant merchant. It is believed that Non-governmental organizations will play a crucial role in overcoming the challenges of entering rural regions ${ }^{22}$

Act No. 8 of 1999 concerning Consumer Protection, in which the rights and obligations of producers and consumers are contained therein, namely Article 4:

1. The right to comfort, security and safety in consuming goods and/or services.

2. The right to choose goods and/or services and to obtain these goods and/or services in accordance with the exchange rates and conditions and guarantees promised

3. The right to correct, clear and honest information regarding the condition and guarantee of goods and/or services

4. The right to have their opinions and complaints heard about the goods and/or services used.

22 Agus Satory, Lasmin Alfies Sihombing, Yeni Nuraeni, and Mustaqim Mustaqim. (2020). 'Analysis of Program Implementation Education of Consumer Protection in Improving Consumer Empowerment Index'. Advances in Social Science, Education and Humanities Research 438. https://doi.org/doi.org/10.2991/assehr.k.200513.071. 
5. The right to get advocacy, protection, and proper consumer protection dispute resolution efforts

6. The right to receive consumer guidance and education.

7. The right to be treated or served correctly and honestly and not to discriminate.

8. The right to get compensation, indemnity and/or replacement, if the goods and/or services received are not in accordance with the agreement or not as it should be.

9. Rights stipulated in other statutory provisions.

This regulation is solely intended to create a balance between consumer and business interests, enforced by legal security that protects consumers' rights and duties and business actors' rights and obligations. However the Act is also not eligible with the increased risk of violating consumer rights along with the presence of the digital economy.

There are a lot of business actors who are cheating by manipulating the scales they use in trading and by doing so, the profits of business actors will increase and vice versa consumers will feel very disadvantaged by this. This of course violates the consumers' rights. In 2019, the Indonesian Consumer Empowerment Index was 41.70 or just at the "capable" level. This means that consumers already recognize their rights but have not been very active in fighting for these rights. In 2019, the number of complaints related to e-commerce platforms was reduced to five from a total of 1,518 complaints. In 2020, the number of complaints related to transactions on e-commerce platforms jumped to 70 or around 11 percent of the total 582 complaints. And In 2020, there were only 299 complaints about trafficking through the electronic system, with the main problem being complained of being related to losses in transactions in electronic commerce, and the main problem in the majority was phishing and account abuse through one-time password (OTP).

In response to the above, the government has demonstrated its initiatives in educating and protecting the public on their rights as consumers. First, the Ministry 
of Trade continues to be committed in promoting consumer protection through various social and competition events such as Harkonas 2020 and Pameran Edukasi Konsumen with the aim of increasing consumer empowerment which is an important key to continue to build consumer trust in Indonesia. In addition, the Ministry of Trade also continues to supervise trade activities and circulated goods and/or services with strategies, namely continuous supervision of PMSE staple foods and health by the Director General of Goods and Services Supervision; Supervision related to standard clause parameters in the terms and conditions of PMSE users, how to sell, guarantees, and advertising; monitoring the data protection of PMSE service users; And the Directorate General of Consumer Protection and Trade and Order also conducts online supervision both from the marketplace with parameters such as clauses for how to sell and advertising, as well as overseeing the extent to which business actors are responsible for consumer protection.

Furthermore, the government has compiled a strategy for the implementation of the Consumer Protection and Business Order (PKTN) program followed by about 150 participants from service representatives from 34 provinces in Indonesia by providing constructive feedback to produce similar perceptions and targeted work programs. According to Article 18 GR No. 80 of 2019, consumers can make their complaint through the Directorate General of PKTN Ministry of Trade by coming directly to the Ministry of Trade's office, sending a letter, via Whatsapp, or through the website https://simpktn.kemendag.go.id.

Second, since being given a place in the laws and regulations in the consumer sector, the participation of non-governmental organizations has increasingly emerged in other fields of law, including the field of consumer protection law. Therefore, the NonGovernmental Organization of Consumer Protection (LPKSM) was formed, which has a position as a partner of the community and the government in protecting efforts for consumer rights. LPKSM's legal basis is GR No. 59 of 2001 concerning LPKSM and GR No. 89 of 2019 concerning Amendments to GR No. 59 of 2001 concerning LPKSM. LPKSM has the duty and function of accommodating consumer complaints, bridging communication between consumers, business actors and/or the government, 
conducting critical studies, organizing advocacy, and even filing a lawsuit in court. To ensure order, certainty and transparency in the implementation of consumer protection, it is deemed necessary for LPKSM to register and report the implementation of its duties to the Provincial Government. LPKSM from Indonesia that registered themselves as members of Consumer International (CI), namely LP2K and YLKI with the aim of increasing and promoting cooperation between countries considering the increasing and fast traffic of goods and services globally 23 .

Third, Consumer protection law enforcement mechanisms require the support of the judicial system. In addition to LPKSM, BPSK, BPKN and the Ministry of Trade, the institution that can also help in solving the consumer protection problems is the police. So this case went into the criminal realm, where the police will conduct an investigation. This happens if the decision of BPSK is not implemented by the business actors in accordance with Article 60 of the Consumer Protection Act.

Forth, in addition to monitoring the businesses performance for the protection of consumers, National Cyber and Cyrpto Agency was formed according to the Presidential Regulation No. 53 of 2017 concerning the National Cyber and Crypto Agency and Presidential Regulation No. 133 of 2017 concering Amendments to Presidential Regulation No. 53 of 2017, where its duties are identification, protection, prevention, recovery, monitoring, control of e-commerce protection, cyber incidents/attacks, cyber diplomacy and cyber contact centres. BSSN has created a platform called Indeks $K A M I$ to assess and evaluate the level of readiness that include the completeness and maturity of information security in an organisation based on the criteria in SNI ISO/IEC 27001. Other than that, Institutions that also worked together with Ministry of Communication and Informatics are Indonesian Security Incident Response Team on Internet (ID-SIRTII) which its tasks is identified possible malware attacks, the Directorate of Cyber Crime (Dittipidsiber) which handles two groups of crimes, namely computer crime and computer-related crime, the Indonesian Computer Emergency Response Team (ID-CERT) which only informs

23 Rosmawati. (2018). "Pokok-Pokok Hukum Perlindungan Konsumen". Edited by Y. Rendy. Depok: Prenadamedia Group. p.107-15. 
various complaints about the network incident, and depends entirely on collaboration with the parties involved, building the Indonesian CERT community and conducting in-depth research. And from education and training sector, there are application for Applied Masters program (M.Tr.) in the field of Multi, Inter, or Transdisciplinary Scientific Networking, and EC-Council and ISACA as cybersecurity organisations providing training program.

Judging from the level of Indonesia's Consumer Empowerment Index, the level has increased by $8.00 \%$ which is from $33.70 \%$ in 2017 (recognised as understanding stage) to $41.70 \%$ in 2019 (recognised as capable stage). And in 2020, the government expects an increase of up to $42 \%{ }^{24}$. This means that Indonesian consumers are capable to use their rights to make consumption choices and to fight for their rights as consumers, as well as they recognise and understand their rights and obligations. This is something to be proud of, but consumers are still hesitant to report violations of their rights as consumers.

\section{4) The Challenges on the Customer Position in The Digital Platform}

The definition of platform according to the Circular Letter of the Minister of Communications and Informatics No. 5 of 2016 is a container in the form of website applications, and/or other internet-based content services used for transactions and/or trading facilities via electronic systems. Digital platforms move almost all human activities, be it economic, social and political. The transformation of platform in the industrial world offers a strong direction on the main economic and social trends of the day, namely the emergence of the platform as an enterprise and organizational paradigm. The growth of many of the biggest, rising and strongest organizations today is powered by this platform model. In addition, the platform is starting to move from health, education and electricity and government to numerous other economic and social fields.

24 Liputan 6. (2020). 'BPKN Akui Indeks Keberdayaan Konsumen Indonesia Masih Rendah'. https://www.liputan6.com/bisnis/read/4376132/bpkn-akui-indeks-keberdayaan-konsumenindonesia-masih-rendah. 
The responsibilities for losses suffered by consumers as a result of using an online platform in buying and selling should also be borne by the providers ${ }^{25}$. Responsibility of this e-commerce platform provider becomes important because in addition to the platform provider is the party that holds the seller to offer their goods or services, the platform provider is authorized to determine what content can be loaded on their platform, or in this case including controlling goods or services for sale. Based on the Article 1800-1806 of the Indonesian Civil Code, the provider as authorised person is entitled for the seller as the authorizer who makes sales to the consumer by providing sites for selling goods or services, informing by giving notification in every order until the item is received by the consumer, and providing a means in the event of a problem in a transaction from the consumer for the goods received from the seller to make a refund and/or goods. Enforcement of terms and conditions on online transaction sites is not a problem as long as it does not conflict with laws and regulations, public order, and morals. It's just that the application of these unilateral terms and conditions must be balanced with better service to consumers and consumers are also given the opportunity to take legal action which is their right as an Indonesian citizen.

The development of a business paradigm for the new method of transactions would lead to a dynamic market of new business models facing digital and conventional industries. Competition between business actors should have a positive effect and advantage on economic development and should enable customers to select their goods. However, the increasing rivalry would definitely result in unregulated competition, if this has an effect which hinders the presence of different business models ${ }^{26}$. Meanwhile, to reveal the practice of monopoly is very difficult to prove in the

25 Emmy Febriani Thalib, and Ni Putu Suci Meinarni. (2019). 'Tinjauan Yuridis Mengenai Marketplace Berdasarkan Peraturan Perundang-Undangan Di Indonesia'. Jurnal IUS Kajian Hukum Dan Keadilan 7 (2). https://doi.org/dx.doi.org/10.29303/ius.v7i2.622.

26 Bambang Leo Handoko, Rudy Aryanto, and Idris Gautama. (2015). 'The Impact of Enterprise Resources System and Supply Chain Practices on Competitive Advantage and Firm Performance: 
world of model disruption of innovation by the business competition authority ${ }^{27}$. Digital business actors are actors within countries with numerous jurisdictions or corporate legislation. Furthermore, monopolistic practices in a borderless global economy are difficult for the government to identify. It would be challenging for regulators to assess where the competitive industries lie and where businesses compete. This has led to another concern for consumers' position in the digital platform.

For instance, price competition is one of the easiest forms of competition to identify. When this price competition is eliminated by entering into a price fixing agreement between business actors, it can result in a consumer surplus that should be enjoyed by buyers or consumers being forced to switch to producers or sellers. Actions taken by business actors aim to make them get higher profits. In comparison, some businesses in their privacy policies, prior to customers being allowed to use the goods provided by the business, claimed that the company would never exchange customer information with a third party. However, when they went bankrupt, any buyer would want customer's information data and therefore would sell them at high cost which indeed violated the law. While a business is not bankrupt or not necessarily sold, its privacy policies could still be disappointing if its consumer details have been used as collateral for a loan ${ }^{28}$. In the existing regulation, Article 95 (A) Government Regulation Act No. 23 of 2006 concerning Population Administration stated those who sell personal data shall be sentenced to imprisonment of 2 years and/or maximum fine of

Case of Indonesian Companies'. Procedia Computer Science 72. https://doi.org/10.1016/j.procs.2015.12.112.

27 Nanda Narendra Putra. (2017) 'KPPU: Sulitnya Melacak Praktik Monopoli Di Era Ekonomi Digital'. Hukumonline.com. Retrieved from https://www.hukumonline.com/berita/baca/lt59f3452e3555b/kppu--sulitnya-melacak-praktikmonopoli-di-era-ekonomi-digital?page=all.

28 Masitoh Indriyani, Nilam Andaria Kusuma Sari, and Satria Unggul W. P., Sari. (2017).' Perlindungan Privasi Dan Data Pribadi Konsumen Daring Pada Online Marketplace System'. Justitia Jurnal Hukum 1, no. (2). https://doi.org/dx.doi.org/10.30651/justitia.v1i2.1152. 
Rp. 25.000.000 (around USD1770). The ITE Act in prosecuting parties who disseminated personal data of citizens will have a penalty of up to 10 years and a fine of Rp. 10 billion (around USD719.397). In case of bankruptcy and transactions, privacy policy shall reveal further information on the effects of a consumer's information. A divulgation of fundamental consumer rights, limits on the data usage, and constraints on the form of organization on which the data will being sold should be preserved. Moreover, consumers should be informed or notified whether their data will be sold in the case of a company loss, as this is in accordance with the obligation of the business stated in the Act No. 8 of 1999 (Consumer Protection Act).

\section{Conclusion}

This paper concluded that in the greater context, consumer protection applies to laws and regulations guaranteeing equal relationships between suppliers of services and customers. In the scope of inherent information asymmetries and market power imbalances, government actions and restrictions on consumer protection are warranted, with businesses providing more information on the good or the service than consumers. A legal framework for consumer protection usually involved increased transparency and awareness of products and services, market competitiveness promotion, fraud prevention, customer satisfaction and the removal of discriminatory practices. With respect to the advancement of connectivity and information technologies, where products or services can be traded to customers across state and national borders, regulatory security for consumers will still be an important topic of concern to address. This is no longer just a geographic symptom, but a systemic epidemic for all the world's customers. State intervention is needed in accordance with the more complicated challenges faced by consumers, so the government has to enact intervention strategies to address the possible damage to consumers. Interventions are made such that the balancing between rights and duties between producers and consumers can be reached. Furthermore, the number and complexity of fraud will continue to grow every year and worsen. All segments of society, including businesses to major supply providers, as well as governments are accelerating the transformation of technology to meet the digital needs that are now no longer just for entertainment. Therefore, awareness and knowledge of cyber 
security has become a necessity for the Indonesian people to avoid fraud, as well as maintain security in the use of digital technology. In emerging economies such as Indonesia, everything rests on trade and business has recently become heavily dependent on electronic communication. Indeed, we will use electronic resources for governance very soon. Legislation to promote the security of personal data would only be helpful if those who use digital technologies can do so confidently, so that businessbased information technology and e-commerce can be built seamlessly. Privacy policy is of considerable significance for establishing trust between businesses, customers, and the society.

\section{References}

\section{Books}

Atsar, Abdul, and Rani Apriani. Buku Ajar Hukum Perlindungan Konsumen. Yogyakarta: CV. Budi Utama, 2019.

Cronin, Mary J. Public Policy And The Internet: Privacy, Taxes, and Contract. Edited by Nicholas Imparato. California: Hoover Institution Press, 2000.

Rosmawati. Pokok-Pokok Hukum Perlindungan Konsumen. Edited by Y. Rendy. Depok: Prenadamedia Group, 2018.

\section{Journal}

Christiani, Theresia Anita. 'Normative and Empirical Research Methods: Their Usefulness and Relevance in the Study of Law as an Object'. Procedia - Social and Behavioral Sciences 201-207 (2016): https://doi.org/10.1016/j.sbspro.2016.05.006.

Darajat, Indra Kirana. 'Perlindungan Hukum Bagi Pelaku Usaha Dan Konsumen Dalam Transaksi Jual Beli Secara Online Dengan Pembayaran Melalui Paypal'. E-Journal Graduate Unpar 1, no. 2 (2014). http://journal.unpar.ac.id/index.php/unpargraduate/article/view/1041/1159.

Fahlevi, Mochammad, Mohamad Saparudin, Sari Maemunah, Dasih Irma, and Muhamad Ekhsan. 'Cybercrime Business Digital in Indonesia'. E3S Web of Conferences 125, no. 21001 (2019). https://doi.org/doi.org/10.1051/e3sconf/201912521001.

Handoko, Bambang Leo, Rudy Aryanto, and Idris Gautama. 'The Impact of Enterprise Resources System and Supply Chain Practices on Competitive Advantage and Firm Performance: Case of Indonesian Companies'. Procedia Computer Science 72 (2015). https://doi.org/10.1016/j.procs.2015.12.112.

Hotana, Melisa Setiawan. 'Industri E-Commerce Dalam Menciptakan Pasar Yang Kompetitif Berdasarkan Hukum Persaingan Usaha'. Jurnal Hukum Bisnis Bonum Commune 1, no. 1 (2018). https://doi.org/doi.org/10.30996/jhbbc.v0i0.1754.

Indriyani, Masitoh, Nilam Andaria Kusuma Sari, and Satria Unggul W. P., Sari. 
'Perlindungan Privasi Dan Data Pribadi Konsumen Daring Pada Online Marketplace System'. Justitia Jurnal Hukum 1, no. 2 (2017). https://doi.org/dx.doi.org/10.30651/justitia.v1i2.1152.

Jayuska, Rizki. 'Keabsahan Kontrak Pada Transaksi E-Commerce Melalui Media Internet Berdasarkan Undang-Undang No 11 Tahun 2008 Tentang Informasi Dan Transaksi Elektronik'. Jurnal Cahaya Keadilan 4, no. 1 (2016). http://ejournal.upbatam.ac.id/index.php/cahayakeadilan/article/view/943.

Latumahina, Rosalinda Elsina. 'Aspek Hukum Perlindungan Data Pribadi Di Dunia Maya'. Jurnal Gema Aktualita 3, no. 2 (2014). http://hdl.handle.net/123456789/92.

Lim, Merlyna. 'The Internet and Everyday Life in Indonesia: A New Moral Panic?' Journal of the Humanities and Social Sciences of Southeast Asia 169, no. 1 (2013). https://doi.org/10.1163/22134379-12340008.

Lukito, Imam. 'Tantangan Hukum Dan Peran Pemerintah Dalam Pembangunan ECommerce'. Jurnal Ilmiah Kebijakan Hukum 11, no. 3 (2017). https://doi.org/dx.doi.org/10.30641/kebijakan.2017.V11.349-367.

Priscyllia, Fanny. 'Perlindungan Privasi Data Pribadi Perspektif Perbandingan Hukum'. $\begin{array}{lllll}\text { Jatiswara no. } & 34, & 3 & \text { (2019). }\end{array}$ https://doi.org/doi.org/10.29303/jatiswara.v34i3.218.

Raeskyesa, Dewa Gede Sidan, and Erica Novianti Lukas. 'Does Digitalization Increase Economic Growth? Evidence from ASEAN8 Countries'. Jurnal Ekonomi Indonesia 8, no. 2 (2019). http://jurnal.isei.or.id/index.php/isei/article/view/33.

Risnain, Muh. 'Konsep Penguatan Kewenangan Komisi Pengawas Persaingan Usaha Sebagai Lembaga Quasi-Peradilan Dalam Membangun Perekonomian Nasional Yang Sehat Dan Adil'. Jurnal IUS Kajian Hukum Dan Keadilan 6, no. 2 (2018). https://doi.org/dx.doi.org/10.29303/ius.v6i2.557.

Rosadi, Sinta Dewi. 'Protecting Privacy On Personal Data In Digital Economic Era: Legal Framework In Indonesia'. Brawijaya Law Journal 5, no. 1 (2018). https://doi.org/dx.doi.org/10.21776/ub.blj.2018.005.01.09.

S, Laurensius Arliman. 'Peranan Metodologi Penelitian Hukum Di Dalam Perkembangna Ilmu Hukum Di Indonesia'. Soumatera Law Review 1, no. 1 (2018). https://doi.org/10.22216/soumlaw.v1i1.3346.

Safiranita, Tasya. 'Aspek Hukum Transaksi Perdagangan Melalui Media Elektronik Dikaitkan Dengan Undang-Undang Nomor 19 Tahun 2016 Tentang Informasi Dan Transaksi Elektronik'. Dialogia Iuridica 8, no. 2 (2017). https://doi.org/doi.org/10.28932/di.v8i2.720.

Satory, Agus, Lasmin Alfies Sihombing, Yeni Nuraeni, and Mustaqim Mustaqim. 'Analysis of Program Implementation Education of Consumer Protection in Improving Consumer Empowerment Index'. Advances in Social Science, Education and Humanities $\quad 438$ https://doi.org/doi.org/10.2991/assehr.k.200513.071.

Suraji, and Pranoto. 'Pemberdayaan Dan Perlindungan Hukum Bagi Konsumen Dalam 
Rangka Melindungi Kepentingan Konsumen Kurang Mampu'. Yustisia Jurnal Hukum 2, no. 3 (2013). https://doi.org/doi.org/10.20961/yustisia.v2i3.10144.

Syamsudin, M. 'The Failure of the Court to Protect Consumers: A Review of Consumer Dispute Resolution in Indonesia'. Journal of Consumer Policy, 2020. https://doi.org/doi.org/10.1007/s10603-020-09470-0.

Thalib, Emmy Febriani, and Ni Putu Suci Meinarni. 'Tinjauan Yuridis Mengenai Marketplace Berdasarkan Peraturan Perundang-Undangan Di Indonesia'. Jurnal IUS Kajian Hukum Dan Keadilan 7, no. 2 (2019). https://doi.org/dx.doi.org/10.29303/ius.v7i2.622.

Tobing, Agustinus Nicholas L. 'Consumer Protection Regulations in Life Insurance Industry and Its Challenges: An Empirical Analysis from Indonesia'. International Journal of Engineering \& Technology 7, no. 4.9 (2018). https://doi.org/10.14419/ijet.v7i4.9.21088.

Wardani, Nizia Kusuma, and Arie Afriansyah. 'Indonesian Legal Challenges Regarding Electronic Contracts in International Trade'. Advances in Economics, Business and Management Research 130

(2020). https://doi.org/doi.org/10.2991/aebmr.k.200321.004.

Widiatedja, I Gusti Ngurah Parikesit. 'Incorporating Local Wisdom Into the Consumer Protection Legal Regime: A Comparison Between Indonesia And Australia'. Udayana Journal of Law and Culture 1, no. 1 (2017). https://doi.org/10.24843/UJLC.2017.v01.i01.p03.

Yue, Guan, Dwidja Priyatno, and Anita Kamilah. 'A Comparison Between Chinese ECommerce Laws And Indonesian Information And Electronic Transactions Laws Against Cross-Border Online Services'. International Journal of Scientific \& Technology Research 8, no. 10 (2019): 3189-94.

Yuniarti, Siti, and Abdul Rasyid. 'Consumer Protection in Lending Fintech Transaction in Indonesia: Opportunities and Challenges'. International Journal of Engineering \& Technology 7, no. 9 (2018). https://doi.org/10.14419/ijet.v7i4.9.21088.

\section{Website}

GBG, and The Asian Banker. 'Future-Proofing Fraud Prevention in Digital Channels: Indonesia's Financial Institution 2020. https://www.gbgplc.com/apac/future-proofing-fraud-prevention-in-digitalchannels-indonesias-financial-institution-

study/?utm_campaign=MKT_APAC_WBN_TABR_ID\&utm_source=PRactivity\&utm _medium=future-proofing.

Liputan 6. 'BPKN Akui Indeks Keberdayaan Konsumen Indonesia Masih Rendah', 2020. https://www.liputan6.com/bisnis/read/4376132/bpkn-akui-indekskeberdayaan-konsumen-indonesia-masih-rendah.

Lidwina, Andrea. 'Penipuan Online, Kejahatan Siber Yang Paling Banyak Dilaporkan'. Databoks, 2019. https://databoks.katadata.co.id/datapublish/2019/10/31/penipuan-onlinekejahatan-siber-paling-banyak-dilaporkan. 
Putra, Nanda Narendra. 'KPPU: Sulitnya Melacak Praktik Monopoli Di Era Ekonomi Digital'. Hukumonline.com, 2017. https://www.hukumonline.com/berita/baca/lt59f3452e3555b/kppu--sulitnyamelacak-praktik-monopoli-di-era-ekonomi-digital?page=all.

Sudiongko, Anggara. '2.259 Laporan Kejahatan Siber Di Situs Bareskrim, Konten Provokatif Mendominasi'. JatimTimes, 2020. https://jatimtimes.com/baca/226427/20201017/072800/2-259-laporankejahatan-siber-di-situs-bareskrim-konten-provokatif-mendominasi.

Syahrul, Yura. 'Indonesia, Pasar E-Commerce Terbesar Di ASEAN Dengan Banyak Kendala'.

Katadata.co.id, 2015. https://katadata.co.id/yurasyahrul/indepth/5e9a56e366037/indonesia-pasare-commerce-terbesar-di-asean-dengan-banyak-kendala.

Wuryasti, Fetry. 'Potensi Besar Ekonomi Digital Indonesia'. Media Indonesia, 2020. https://mediaindonesia.com/ekonomi/354089/potensi-besar-ekonomi-digitalindonesia.

Yozami, M. Agus. 'Meneropong Perlindungan Konsumen Jasa Finansial Di Tahun Tikus Logam'. Hukumonline.com. Accessed 1 September 2020. https://www.hukumonline.com/berita/baca/lt5e54e4e9c5d97/meneropongperlindungan-konsumen-jasa-finansial-di-tahun-tikus-logam?page=all/.

\section{Regulation}

Act No. 5 of 1999 concerning Prohibition of Monopoly Practice and Unhealthy Business Competition

Act No. 8 of 1999 concerning Consumer Protection

Act No. 7 of 2014 on Trade

Act No. 19 of 2016 concerning Amendments to Act No. 11 of 2008 on Information and Electronic Transactions

Government Regulation No. 71 of 2019 concerning Application of Electronic Systems and Transactions

Government Regulation No. 80 of 2019 concerning Electronic Commerce

Indonesian Civil Code 